\title{
THE BLOOD LEVELS AND RENAL CLEARANCE IN RABBITS AND MAN OF AN ANTIBIOTIC DERIVED FROM B. SUBTILIS (BACITRACIN)
}

\author{
BY HARRY EAGLE, ELLIOT V. NEWMAN, ROGER GREIF, T. M. BURKHOLDER, \\ AND S. C. GOODMAN 1 \\ WITH THE TECHNICAL ASSISTANCE OF ARLYNE D. MUSSELMAN \\ (From The Laboratory of Experimental Therapeutics of the U. S. Public Health Service and \\ The Johns Hopkins School of Hygiene, The Johns Hopkins Medical School, \\ and the U.S. Marine Hospital, Baltimore, Maryland)
}

(Received for publication April 16, 1947)

The renal clearances of penicillins $F, G$, and $X$ have been shown to approximate the total renal plasma flow $(1,2)$, varying between 529 and 865 ml. per minute in man, and 23 to $111 \mathrm{ml}$. per minute in rabbits (2). In consequence of that rapid excretion, the serum concentration of penicillin $G$ decreases after its intramuscular injection in aqueous solution, at an average rate of 2 to 3 per cent of the residual penicillin per minute, and 70 to 80 per cent per hour; and it disappears from the blood even more rapidly after intravenous injection $(3,8)$. A therapeutic agent equal to penicillin in bactericidal activity, but with a slower rate of absorption or excretion, would provide effective levels for longer periods of time, and might be correspondingly more effective than penicillin similarly injected.

The antibiotic agent discovered. by Johnson, Anker and Meleney (4) in culture filtrates of a strain of B. subtilis (Tracy), and termed by them bacitracin, possesses some of these properties. As will be here shown, it is excreted by both rabbits and man at a rate which corresponds approximately to the rate of glomerular filtration, rather than to the total renal plasma flow. In consequence, the blood levels observed after its intravenous or intramuscular injection fall off more slowly than do those of penicillin, and a given dosage provides effective levels for longer periods. The implications of these findings with respect to the therapeutic efficacy of this agent are discussed in the text.

\section{METHODS AND MATERIALS}

Bacitracin. Three different lots of bacitracin were used in these studies. The courtesy of Dr. Frank L. Meleney

\footnotetext{
${ }^{1}$ Supported in part by the Life Insurance Medical Research Fund.
}

in facilitating their procurement is gratefully acknowledged. The 3 lots, designated in the tables as $A$, B-100, and PB-1, had relative gravimetric activities in vitro against the $\mathrm{C}-203$ strain of Streptococcus pyogenes of 100,165 , and 330 , respectively. Their activity in terms of the unit as defined by Meleney and his co-workers (4) was 18,30 , and 60 units per mgm., respectively. Lot PB-1 was concentrated in this laboratory from a commercial lot, B-103.

Blood specimens in rabbits were obtained by cardiac puncture, and urine specimens by bladder catheterization and irrigation.

Method of assay. A modified Rammelkamp-RantzKirby method $(5,6)$, in which inhibition of hemolysis by the C-203 strain of Streptococcus pyogenes served as the endpoint, was used to assay the levels of the antibiotic in the blood and urine. The endpoint was not as sharp as with penicillin, and somewhat coarser interpolations were used than had proved feasible with the latter drug $(2,7)$. The unknown sample, in appropriate dilution as determined by a preliminary spot-assay, was distributed in amounts of $0.8,0.64,0.48,0.4,0.32,0.24,0.2$ ... ml., and the volumes brought up to $0.8 \mathrm{ml}$. with broth. To all the tubes were then added $0.5 \mathrm{ml}$. of 4 per cent rabbit (or human) blood broth, inoculated with $1 / 2,500$ part of a fresh 6- to 8-hour culture of the organism in blood broth. Difficulties introduced by the occasional contaminated specimen were overcome by removing the assays from the incubator after 6 to 8 hours, when the streptococci had multiplied sufficiently to initiate hemolysis, but before they had been overgrown by the contaminant. The tubes were then allowed to stand at room temperature overnight, and the results read the next morning.

The threshold concentration for inhibition under the conditions of this assay averaged on the order of 0.01 "units" per ml., or $0.3 \mu \mathrm{g}$. of the impure preparation B100. The threshold concentration of penicillin $G$ under the same conditions was $0.015 \mu \mathrm{g}$. per ml.

\section{EXPERIMENTAL}

Blood levels of bacitracin in rabbits and man. Nine human subjects were injected intramuscularly with bacitracin in aqueous solution at dosages 
varying from 14 to 150 units per $\mathrm{kgm}$., representing 0.8 to $5 \mathrm{mgm}$. per $\mathrm{kgm}$. of the preparations used. Rabbits were injected both intravenously and intramuscularly at dosages varying from 10.8 to 1,080 units per $\mathrm{kgm}$. ( 0.6 to $60 \mathrm{mgm}$. per $\mathrm{kgm}$.). The blood levels at varying intervals thereafter are graphically summarized in Figures 1 and 2, in which the bacitracin dosages and blood levels are expressed both as units and milligrams in order to permit comparison with the average curves given by penicillin $\mathrm{G}$ similarly injected.

In individual rabbits, the serum concentrations at any given time were linearly related to the dosage injected; and the average curves of Figure 1 reflect the constancy of that relationship. In man, the relationship between dosage and blood level was evident, but less regular (Table I).

There was a striking difference between the rate at which bacitracin and penicillin $G$ disappeared from the blood. In rabbits injected intravenously, bacitracin disappeared from the blood at an average. rate of 50 per cent of the residual activity per hour. With penicillin $G$, the hourly rate of fall has previously been found to be 70 to 80 per cent after

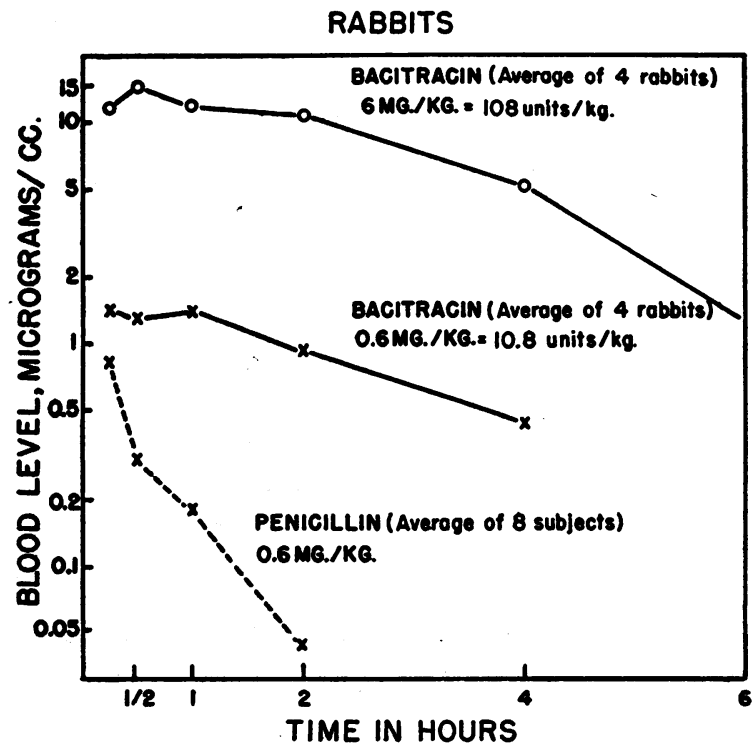

Fig. 1. The Average Blood Level of Bacitracin in RABbits AFTER ITS INTRAMUSCULAR INJECTION AT 6 MgM. PER KGM. ANd 0.6 MgM. PER KGM. OF THE CRUde PREPARAtion A, Corresponding to 108 and 10.8 Meleney-JohnSON UNITS PER KGM.

The blood levels are expressed in micrograms to permit comparison with the penicillin curve; the activity in units would be 0.018 times the levels shown in the figure.
TABLE I

Blood levels of bacitracin after its intramuscular injection in man

\begin{tabular}{|c|c|c|c|c|c|c|c|c|c|c|}
\hline \multirow{3}{*}{$\begin{array}{l}\text { Sub- } \\
\text { ject }\end{array}$} & & & \multicolumn{8}{|c|}{ Time in hours } \\
\hline & \multicolumn{2}{|c|}{ Dosage } & $z$ & $\frac{1}{3}$ & 1 & 2 & 4 & 6 & 8 & 24 \\
\hline & & & \multicolumn{8}{|c|}{ Blood levels } \\
\hline & $\begin{array}{c}\text { mgm. } \\
\text { per }\end{array}$ & $\begin{array}{l}\text { units } \\
\text { per }\end{array}$ & \multicolumn{8}{|c|}{ units per ml. $\times 10^{-2}$} \\
\hline $\begin{array}{l}\text { W. H. } \\
\text { F. E. }\end{array}$ & 5 & 150 & 6 & $\begin{array}{l}19 \\
19\end{array}$ & $\begin{array}{l}43 \\
25\end{array}$ & $\begin{array}{l}43 \\
33\end{array}$ & $\begin{array}{l}2.0 \\
1.7\end{array}$ & & $\begin{array}{r}<1.5 \\
3.0\end{array}$ & $1<$ \\
\hline J. M. & 4 & 120 & & 6.6 & 19 & 23 & 7.5 & 1.5 & $<$ & \\
\hline T. B. & 3 & 90 & 10 & 20 & 27 & 14 & 7.2 & 2.3 & 1.8 & \\
\hline J. P. & 2 & 60 & 4.5 & 12.0 & 20 & 29 & 14 & $<1.5$ & & \\
\hline $\begin{array}{l}\text { L. C. } \\
\text { J. A. }\end{array}$ & 1.5 & 45 & $\begin{array}{l}1.8 \\
4.5\end{array}$ & $\begin{array}{l}3.3 \\
7.2\end{array}$ & $\begin{array}{r}6 \\
12\end{array}$ & $\begin{array}{r}3.6 \\
12.0\end{array}$ & $\begin{array}{l}1.8 \\
3.6\end{array}$ & $<\begin{array}{r}2.5 \\
2.3\end{array}$ & & \\
\hline G. H. & 1.1 & 20 & 3 & 3.8 & 3.8 & 2.5 & $<$ & & & \\
\hline D. K. & & 15 & 1.8 & 3.0 & 3.8 & 3.3 & 1.5 & & & \\
\hline
\end{tabular}

All except last 2 patients (G. H. and D. K.) injected with same lot of material (B-100).

intramuscular injection, and even greater after intravenous injection. The qualitative difference between penicillin and bacitracin is apparent on comparing the appropriate curves in Figures 1 and 2. In rabbits, one hour after the injection of penicillin $\mathrm{G}$ and (crude) bacitracin in equal gravimetric dosage, the serum levels of bacitracin were 8 to 20 times greater than those of penicillin; and 2 hours after the injection, the difference was 20 - to 100 fold. In man also (Figure 2 and Table I), the blood levels 2 hours after the injection of bacitracin

\section{TABLE II}

The varying periods for which bacitracin and penicillin, similarly injected, remained in the circulating blood

\begin{tabular}{|c|c|c|c|}
\hline & \multirow[t]{2}{*}{ Dosage } & \multicolumn{2}{|c|}{$\begin{array}{l}\text { Average number of hours } \\
\text { indicated drug remained } \\
\text { in serum at minimum } \\
\text { level of } 1 \text { g. per ml. }\end{array}$} \\
\hline & & Penicillin & Bacitracin* \\
\hline$\underset{\text { (intramuscular) }}{\text { Man }}$ & $\begin{array}{c}\text { mgm. per kgm. } \\
3 \\
1.5\end{array}$ & $\begin{array}{l}2.1 \\
1.2\end{array}$ & $\begin{array}{c}6.8 \\
2.5,4.6\end{array}$ \\
\hline $\begin{array}{c}\text { Rabbit } \\
\text { (intravenous) }\end{array}$ & $\begin{array}{l}60 \\
6 \\
0.6\end{array}$ & $\begin{array}{l}1.5 \\
0.9 \\
0.25\end{array}$ & $\begin{array}{l}9-10 \\
5.7 \\
1.6\end{array}$ \\
\hline
\end{tabular}

The penicillin blood levels in man are average of 8 subjects (9). The penicillin levels in rabbit are from single animals only. Bacitracin levels are from the experiments of Table I and Figures 1 and 2.

$* 1 \mu \mathrm{g}$. per $\mathrm{ml}$. of crude preparations here used $=0.03$ Meleney-Johnson unit. 


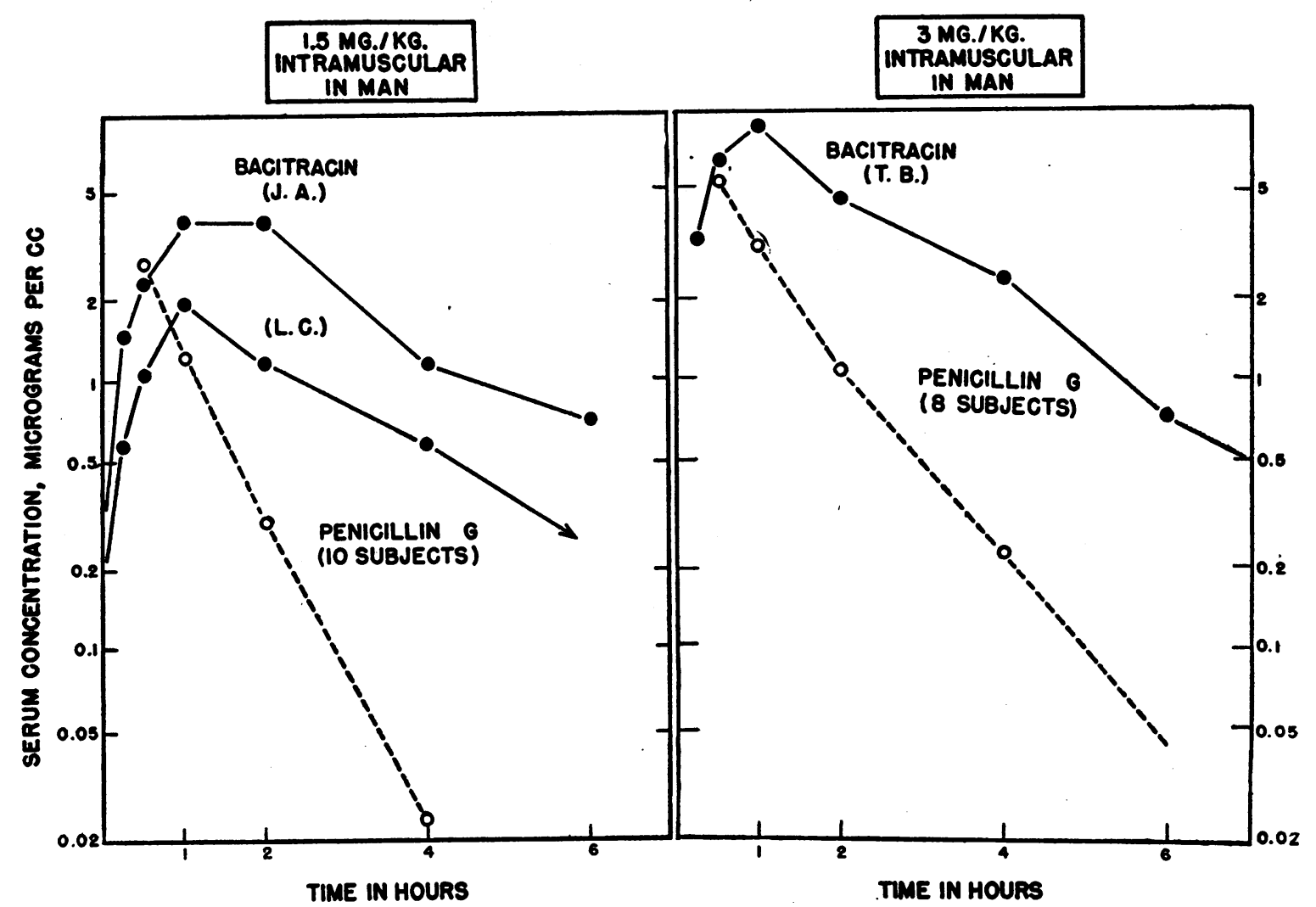

Fig. 2. The Average Blood Levels Afforded by Bacitracin in Man after ITS INTRAMUSCULAR INJECTION AT 1.5 MGM. PER KGM. AND 3 MGM. PER KGM. OF THE Crude Preparation B-100, Corresponding to 45 and 90 Meleney-Johnson Units PER KGM.

The blood levels are expressed in micrograms to permit comparison with the penicillin curve; the activity in units would be 0.030 times the levels shown in the figure.

at e.g., $3 \mathrm{mgm}$. per $\mathrm{kgm}$. (90 units per $\mathrm{kgm}$.), were 4 times greater than the average observed with penicillin $\mathrm{G}$; and the difference became progressively more pronounced thereafter.

A more important comparision between the 2 antibiotics is the length of time for which effective bactericidal levels were maintained. The pertinent data are summarized in Table II. In 2 subjects (J. A. and L. C.), injected intramuscularly with crude bacitracin B-100 at $1.5 \mathrm{mgm}$. per $\mathrm{kgm}$. = 45 units per kgm., a level of $1 \mu \mathrm{g}$. $=0.03$ unit per ml. was maintained for 2.5 and 4.6 hours (Figure 2). In 8 subjects similarly injected with penicillin $G$, that level was maintained for an average period of 1.2 hours (8). In subject T. B., injected with bacitracin at $3 \mathrm{mgm}$. per $\mathrm{kgm} .=90$ units per $\mathrm{kgm}$., the $1-\mu \mathrm{g}$. level was maintained for 6.8 hours, as compared to an average of 2.1 hours in $8 \mathrm{pa}-$ tients receiving the same amount of penicillin $G$ (8). In rabbits also, whether injected at 0.6 or $6 \mathrm{mgm}$. per kgm., a serum concentration of active material corresponding to $1 \mu \mathrm{g}$. per $\mathrm{ml}$. was maintained 6 to 7 times longer with bacitracin than with penicillin.

Urine excretion of bacitracin. The pharmacologic basis for the marked difference in the blood levels afforded by penicillin and bacitracin is their widely different rate of urinary excretion. In 8 human subjects (Table III and Figure 3), the cumulative excretion of bacitracin in $1,2,4$, and 6 hours averaged 17, 34, 66 and 87 per cent. $^{2}$

2 In $\mathbf{5}$ of the subjects listed in Table $I$, the total urinary excretion after 6 to 8 hours varied between 78 and 119 per cent of the amount injected, reflecting essentially com- 
TABLE III

The urinary excretion of bacitracin after its intramuscular injection in man

\begin{tabular}{|c|c|c|c|c|c|c|c|c|c|}
\hline \multirow{2}{*}{ Subject } & \multirow{2}{*}{\multicolumn{2}{|c|}{ Dosage }} & \multicolumn{7}{|c|}{ Time in hours } \\
\hline & & & $\frac{1}{3}$ & 1 & 2 & 4 & 6 & 8 & 24 \\
\hline \multirow[b]{2}{*}{$\begin{array}{l}\text { W.H. } \\
\text { F.E. }\end{array}$} & 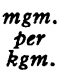 & $\begin{array}{c}\text { units } \\
\text { per } \\
\text { kgm. }\end{array}$ & \multicolumn{7}{|c|}{ Cumulative percentage of bacitracin excreted } \\
\hline & 5 & 150 & 2.5 & $\begin{array}{r}12.6 \\
8.4\end{array}$ & 25.4 & $\begin{array}{l}78.2 \\
51.9\end{array}$ & & $\begin{array}{r}105.7 \\
78.4\end{array}$ & $\begin{array}{r}114.2 \\
95.4\end{array}$ \\
\hline J. M. & 4 & 120 & 24.3 & 33 & 42.6 & $(125.8)^{*}$ & $(155)$ & $(163.8)$ & \\
\hline T. B. & 3 & 90 & 6.5 & 22.3 & 50.5 & 92.9 & 111.4 & 118.5 & \\
\hline $\begin{array}{l}\text { L. C. } \\
\text { J. A. }\end{array}$ & 1.5 & 45 & 5.4 & $\begin{array}{l}15.4 \\
11\end{array}$ & $\begin{array}{l}32.5 \\
29.8\end{array}$ & $\begin{array}{l}68.2 \\
59\end{array}$ & 87.7 & 97.3 & \\
\hline $\begin{array}{l}\text { G. H. } \\
\text { D. K. }\end{array}$ & $\begin{array}{l}1.1 \\
0.82\end{array}$ & $\begin{array}{l}20 \\
15\end{array}$ & $\begin{array}{l}6.8 \\
4.5\end{array}$ & $\begin{array}{l}19.2 \\
12.5\end{array}$ & $\begin{array}{l}29.5 \\
30.4\end{array}$ & 47.8 & & & \\
\hline \multicolumn{3}{|c|}{ Range, per cent } & 4.5 to 24 & 8.4 to 33 & 25.4 to 50.5 & 47.8 to 92.9 & 82 to 111 & 78.4 to 118.5 & \\
\hline \multicolumn{3}{|c|}{ Mean per cent excreted } & 8.4 & 16.8 & 34.4 & 66.3 & 87 & 100 & \\
\hline \multicolumn{4}{|c|}{$\begin{array}{l}\text { Average excretion in } 3 \text { subjects given } \\
\text { penicillin } G \text { intramuscularly }\end{array}$} & 60 & 72 & 78 & 86 & & \\
\hline \multirow{2}{*}{\multicolumn{3}{|c|}{$\begin{array}{l}\text { Hourly excretion in indi- } \\
\text { cated period }\end{array}$}} & Bacitracin & 16.8 & 17.6 & 16.0 & 10.3 & 6.5 & \\
\hline & & & Penicillin & 60.0 & 12 & 3.0 & 4.0 & & \\
\hline
\end{tabular}

* Anomalous high results in parentheses not included in calculation of mean excretion.

The corresponding values for penicillin $G$ have been previously reported to be $60,72,78$, and 86 per cent (8). In the first hour, penicillin $G$ was therefore excreted 3 times faster than bacitracin (Figure 4); after 2 hours, however, when most of the penicillin had already appeared in the urine, and its rate of excretion in the following 2 hours had fallen to 3 per cent per hour, the rate of urine excretion of bacitracin was still 16 per cent per hour, 5 times that of penicillin. The shapes of the blood curves mirror the differences in the rate of excretion of the 2 antibiotics.

In rabbits also (Table IV, and Figures 3 and 4) from 7.5 to 26 per cent (averaging 17 per cent) had appeared in the urine in the first hour, as compared with 58 per cent for penicillin G (3); but after 2 hours, bacitracin was being excreted at an plete excretion. In 1 subject (J. M.), however, the cumulative total of 164 per cent exceeded the experimental error of the method of assay. An even greater anomalous excretion was observed in patient $\mathrm{J}$. P. In both cases, the anomalous result was due to an abnormally high excretion during the 2- to 4-hour period, as yet unexplained. hourly rate of 14 per cent, or 1.7 times greater than penicillin similarly injected. Beyond that time period, only insignificant amounts of penicillin were recovered in the urine, while bacitracin was still being excreted in appreciable quantity.

The renal clearance of bacitracin. Nine experiments to determine the renal clearance of bacitracin in man are summarized in Table $\mathrm{V}$, and one experiment is graphically summarized in Figure 5. The results varied considerably from subject to subject, and even in successive time periods in the same subject. To some extent, the latter variation may have reflected incomplete voiding, since only 2 of the patients were catheterized. The average clearances in the 9 subjects varied between 105 and $283 \mathrm{ml}$. per minute, averaging 159 . The corresponding average values for penicillins $F, G$, and $X$ in man have been found to be 725,560 , and $710 \mathrm{ml}$. per minute (2). The renal clearance of bacitracin in man is therefore approximately $1 / 2$ to $1 / 6$ that of penicillin, explaining the more prolonged blood levels and the more sustained but initially lower rate of urinary excretion of the former. 
The ratio of the bacitracin clearance to the total renal plasma flow (calculated) in these 8 subjects, given in column 5 of Table $\mathrm{V}$, varied between 0.15 and 0.39 , averaging 0.23 .

The ratio of the bacitracin clearance to the (calculated) glomerular filtration rate, given in Column 6 of Table V, varied between 0.8 and 2.04, averaging 1.23. As is indicated in the foregoing section, a significant error in clearance was introduced in 7 of the 9 subjects by the fact that the urine specimens were probably inaccurately voided. Particularly in these patients, the ratio of the renal clearance of bacitracin to the glomerular filtration rate simultaneously determined by the clearance of thiosulfate (9) was of greater significance than the absolute values of either, since an error in urine collection would not affect the ratio of the 2 clearances. This ratio of bacitracin clearance to thiosulfate clearance varied between 0.52 and 1.83 , averaging 1.1.

Eight experiments to determine the renal clearance of bacitracin in rabbits are summarized in Table VI, and one experiment is shown in Figure 6. In these 8 rabbits the renal clearance of bacitracin varied between 2.0 and $7.1 \mathrm{ml}$. per minute, averaging 4.1. This is less than the glomerular filtration rate in the rabbit (10), and is to be compared with an average renal clearance in that species for penicillins $F, G$, and $X$ of 34,61 , and 36 $\mathrm{ml}$. per minute, with a range of 18 to 100 (2). The

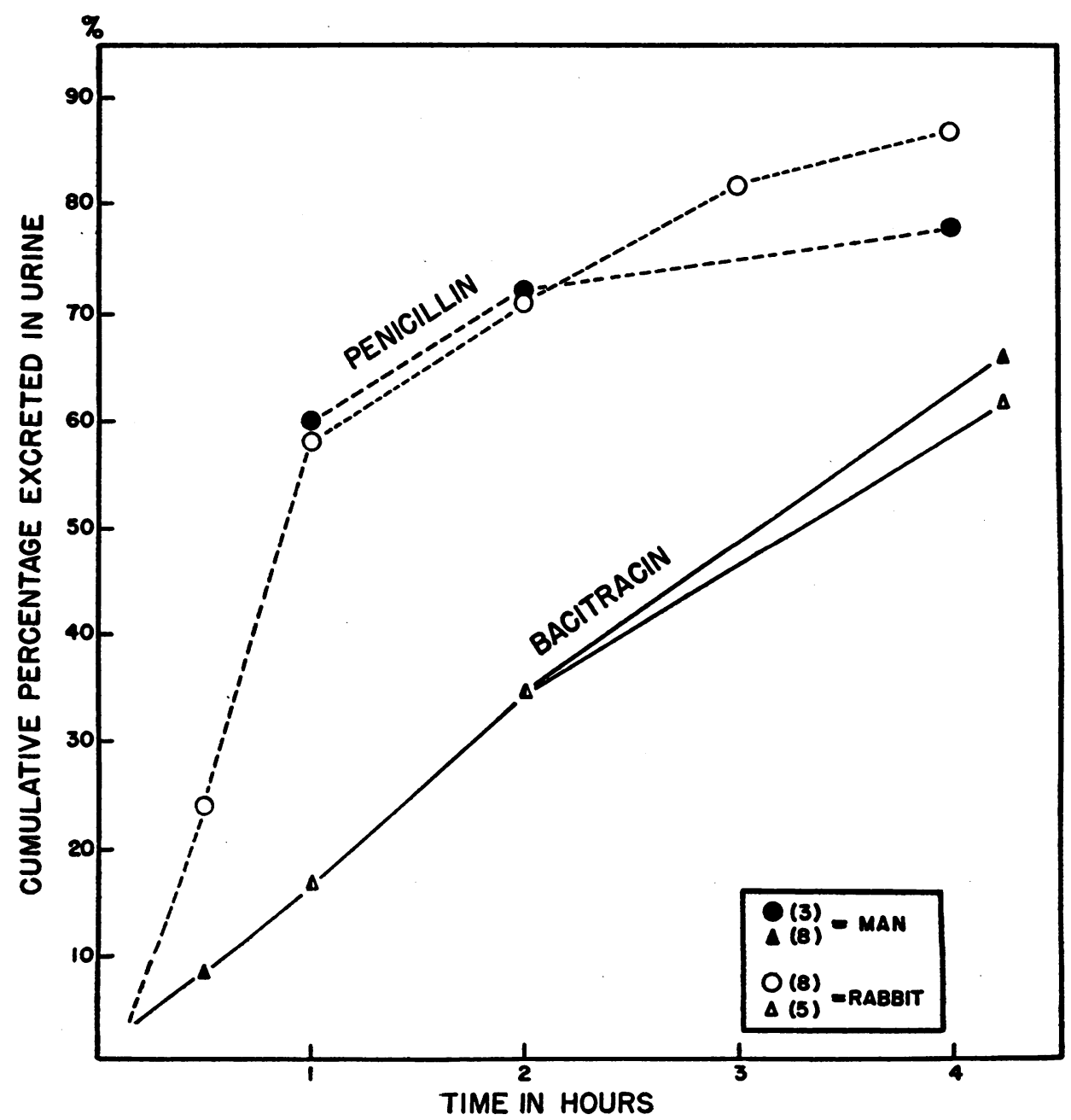

Fig. 3. The Average Cumulative Excretion of Penicilitin and Bactracin in Man AND RABBIT 


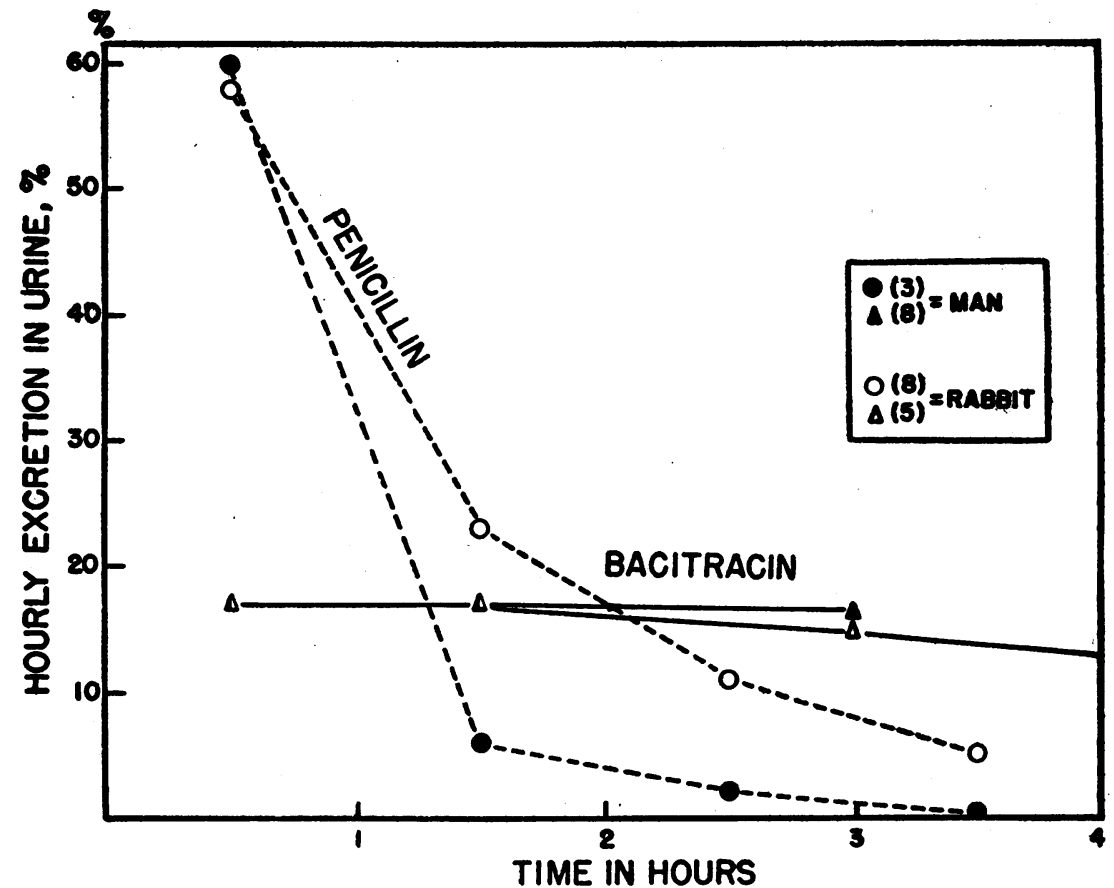

Fig. 4. The Hourly Excretion of Penicillin and Bacitracin in Man and RABbit after their Intramuscular InJection

TABLE IV

The urinary excretion of bacitracin and penicillin in rabbits

\begin{tabular}{|c|c|c|c|c|c|c|c|c|c|}
\hline \multirow{2}{*}{$\begin{array}{l}\text { Route } \\
\text { of } \\
\text { injec- } \\
\text { tion }\end{array}$} & \multirow{2}{*}{\multicolumn{2}{|c|}{ Dosage }} & \multicolumn{7}{|c|}{ Time in hours } \\
\hline & & & $\mathbf{b}$ & 1 & 2 & 3 & 4 & 8 & 24 \\
\hline \multirow{4}{*}{$\begin{array}{l}\text { Intra- } \\
\text { muscu- } \\
\text { lar }\end{array}$} & $\begin{array}{c}\begin{array}{c}m g m \\
\text { per } \\
\text { kgm. }\end{array} \\
\end{array}$ & $\begin{array}{c}\text { units } \\
\text { per } \\
\text { kgm. }\end{array}$ & \multicolumn{7}{|c|}{$\begin{array}{l}\text { Cumulative percentage of bacitracin } \\
\text { excreted in the urine }\end{array}$} \\
\hline & 6.0 & 18.0 & 2.2 & $\begin{array}{r}7.5 \\
9.0 \\
21.1\end{array}$ & $\begin{array}{l}19.5 \\
15.0 \\
45.5\end{array}$ & & $\begin{array}{l}42.8 \\
72.5\end{array}$ & $\begin{array}{l}49.2 \\
76.8\end{array}$ & 78.6 \\
\hline & 0.6 & 10.8 & 8.0 & $\begin{array}{l}25.6 \\
21.0\end{array}$ & $\begin{array}{l}51.4 \\
36.9\end{array}$ & - & 70.6 & & \\
\hline & & & Mean & 17 & 34 & & 62 & & \\
\hline \multirow{3}{*}{$\begin{array}{l}\text { Intra- } \\
\text { venous }\end{array}$} & 6.0 & 18.0 & & $\begin{array}{l}31.4 \\
17.5\end{array}$ & $\begin{array}{l}56.0 \\
30.0\end{array}$ & 42.3 & $\begin{array}{l}63.7 \\
51.1\end{array}$ & 66.5 & \\
\hline & 0.6 & 10.8 & & 33.5 & 47.1 & & 54.6 & & \\
\hline & & & Mean & 27.5 & 44.4 & & 56.5 & & \\
\hline \multicolumn{4}{|c|}{$\begin{array}{l}\text { Mean in } 7 \text { rabbits injected } \\
\text { intramuscularly with pen- } \\
\text { icillin G }\end{array}$} & 58 & 71 & & 87 & 87 & \\
\hline \multirow{2}{*}{\multicolumn{2}{|c|}{$\begin{array}{l}\text { Hourly rate of } \\
\text { excretion after } \\
\text { intramuscular } \\
\text { injection }\end{array}$}} & \multicolumn{2}{|c|}{ Bacitracin } & 17 & 17 & & 14 & & \\
\hline & & \multicolumn{2}{|c|}{ Penicillin } & 58 & 13 & & 8 & & \\
\hline
\end{tabular}

latter values approximate the total renal plasma flow.

DISCUSSION

It is evident from the foregoing data that the antibiotic substances present in culture filtrates of

TABLE V

Renal clearance of bacitracin in man

\begin{tabular}{|c|c|c|c|c|c|c|}
\hline \multirow{2}{*}{$\begin{array}{l}\text { Sub- } \\
\text { ject }\end{array}$} & \multirow{2}{*}{$\begin{array}{l}\text { Dos- } \\
\text { age }\end{array}$} & \multirow{2}{*}{$\begin{array}{c}\text { Average } \\
\text { clearance } \\
\text { bacitracin }\end{array}$} & \multirow{2}{*}{$\begin{array}{c}\text { Calc'd } \\
\text { renal } \\
\text { plasma } \\
\text { flow* }\end{array}$} & \multirow{2}{*}{$\begin{array}{c}\text { Ratio } \\
\text { bacitracin } \\
\text { clearance } \\
\text { to total } \\
\text { plasma } \\
\text { flow* }\end{array}$} & \multicolumn{2}{|c|}{$\begin{array}{l}\text { Ratio of bacitracin } \\
\text { clearance to glomer- } \\
\text { ular filtration rate }\end{array}$} \\
\hline & & & & & $\begin{array}{l}\text { As calcu- } \\
\text { lated } \\
\text { from } \\
\text { ourface } \\
\text { area }\end{array}$ & $\begin{array}{l}\text { Experi- } \\
\text { mentaly } \\
\text { det'd with } \\
\text { sodium } \\
\text { thiosulfate }\end{array}$ \\
\hline $\begin{array}{l}\text { H.W } \\
\text { F. E. } \\
\text { T. B. } \\
\text { J. P. } \\
\text { L. C. } \\
\text { J. A. } \\
\text { G. H. } \\
\text { D. K. }\end{array}$ & $\begin{array}{l}\text { mgm. } \\
\text { per } \\
\mathrm{kgm} . \\
5 \\
5 \\
3 \\
3 \\
2 \\
1.5 \\
1.5 \\
1.1 \\
0.82\end{array}$ & $\begin{array}{c}\text { ml. per } \\
\text { mis. } \\
115 \\
105 \\
219 \\
170 \\
283 \\
104 \\
139 \\
141\end{array}$ & $\begin{array}{l}705 \\
665 \\
705 \\
638 \\
732 \\
672 \\
613 \\
752\end{array}$ & $\begin{array}{l}0.16 \\
0.16 \\
0.31 \\
0.24 \\
0.39 \\
0.15 \\
0.23 \\
0.19\end{array}$ & $\begin{array}{l}0.87 \\
0.8 \\
1.65 \\
1.44 \\
2.04 \\
0.82 \\
1.2 \\
1.0\end{array}$ & $\begin{array}{l}0.92 \\
0.52 \\
1.01 \\
0.93 \\
1.83 \\
0.78 \\
1.68 \\
1.26\end{array}$ \\
\hline \multicolumn{2}{|c|}{ Mean values } & 159 & 695 & 0.23 & 1.23 & 1.1 \\
\hline
\end{tabular}

* Calculated from surface area. 
certain strains of B. subtilis (bacitracin) remain in the circulating blood for significantly longer periods and at higher levels than does penicillin similarly injected. This reflects the fact that the renal clearance of bacitracin was of the same order of magnitude as the glomerular filtration rate, as compared to a renal clearance for penicillins $F, G$, and $\mathrm{X}$, approximating the total renal plasma flow.

The mechanism whereby bacitracin is excreted by the kidney is not clear from the present data.

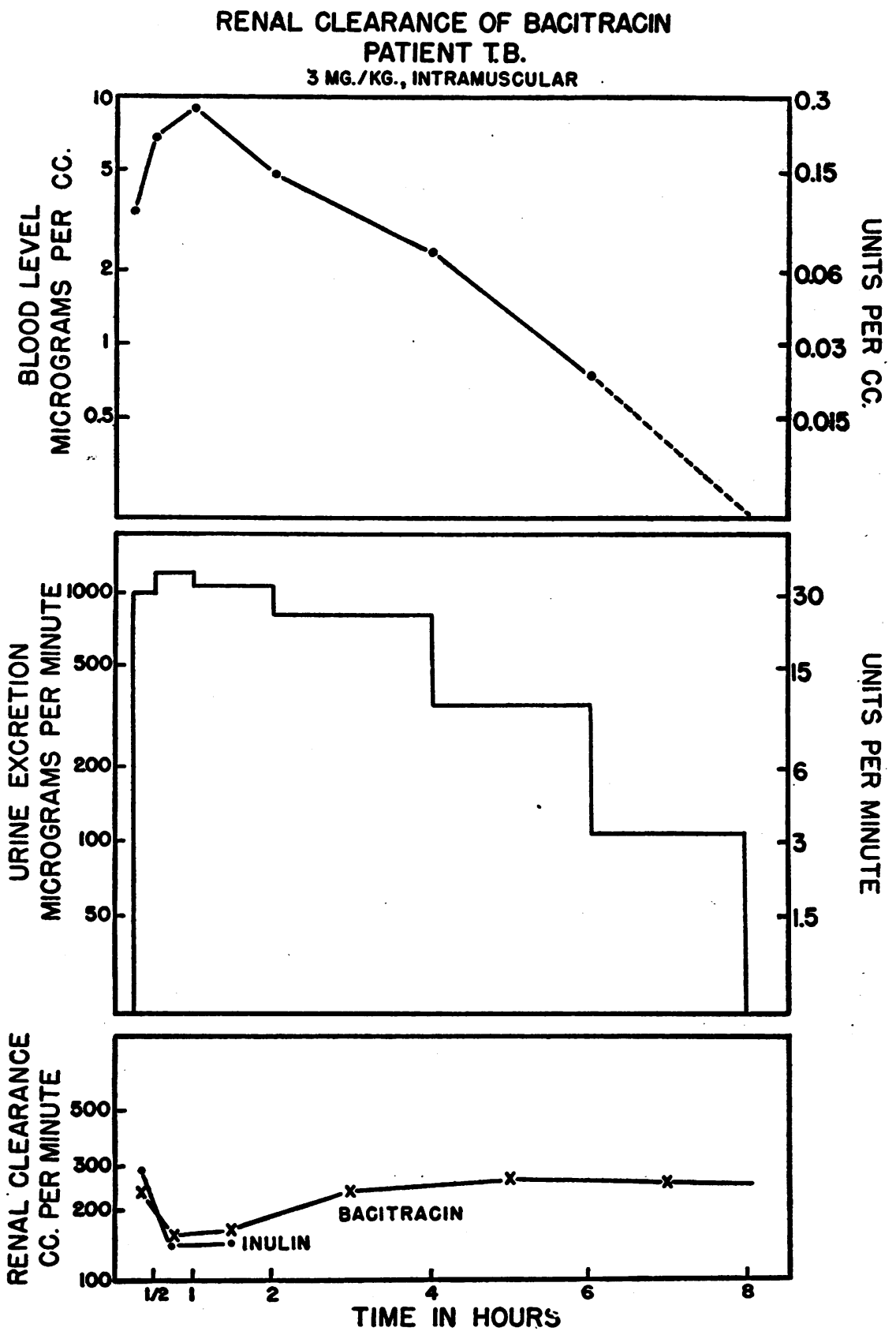

Fig. 5. Illustrating the Low Renal Clearances of Bacitracin in Man

Subject T. B. was injected with Preparation B-100 at $3 \mathrm{mgm}$. per $\mathrm{kgm}$. $=90$ Meleney-Johnson units per kgm. 
TABLE VI

The renal clearance of bacitracin in rabbits

\begin{tabular}{|c|c|c|c|c|c|c|c|}
\hline $\begin{array}{l}\text { Dos- } \\
\text { age }\end{array}$ & $\begin{array}{l}\text { Rab- } \\
\text { bit } \\
\text { no. }\end{array}$ & $\begin{array}{l}\text { Route of } \\
\text { injection }\end{array}$ & $\begin{array}{l}\text { Time of } \\
\text { urine } \\
\text { collection }\end{array}$ & $\begin{array}{l}\text { Urine } \\
\text { baci- } \\
\text { tracin }\end{array}$ & $\begin{array}{l}\text { Aver- } \\
\text { age } \\
\text { blood } \\
\text { level }\end{array}$ & $\begin{array}{l}\text { Renal } \\
\text { clear- } \\
\text { ance }\end{array}$ & $\begin{array}{c}\text { Aver- } \\
\text { age }\end{array}$ \\
\hline $\begin{array}{c}\text { mem. } \\
\text { per } \\
\text { kem. }\end{array}$ & 5883 & $\begin{array}{l}\text { Intra- } \\
\text { venous }\end{array}$ & $\begin{array}{l}0 \text { to } 1 \mathrm{hrs} . \\
1 \text { to } 2 \\
2 \text { to } 4\end{array}$ & $\begin{array}{c}\underset{\text { per }}{\operatorname{mgm} .} \\
\operatorname{min.*} \\
\mathbf{8 . 6} \\
\mathbf{3 . 5} \\
\mathbf{0 . 9 8}\end{array}$ & $\begin{array}{l}\text { mgm. } \\
\text { per. } \\
\text { ml.* } \\
1.7 \\
1.08 \\
0.5\end{array}$ & $\begin{array}{c}\text { ml. } \\
\text { per } \\
\text { min. } \\
5.0 \\
3.2 \\
2.0\end{array}$ & 3.4 \\
\hline \multirow[t]{2}{*}{0.6} & 5897 & $\begin{array}{l}\text { Intra- } \\
\text { muscular }\end{array}$ & $\begin{array}{l}0 \text { to } 1 \mathrm{hrs} . \\
1 \text { to } 2 \\
2 \text { to } 4\end{array}$ & $\begin{array}{l}5.8 \\
5.8 \\
2.15\end{array}$ & $\begin{array}{l}1.1 \\
0.9 \\
0.57\end{array}$ & $\begin{array}{l}5.3 \\
6.4 \\
3.8\end{array}$ & 5.2 \\
\hline & 6064 & $\begin{array}{l}\text { Intra- } \\
\text { muscular }\end{array}$ & $\begin{array}{l}0 \text { to } 33 \text { mins. } \\
33 \text { to } 68 \\
68 \text { to } 130\end{array}$ & $\begin{array}{l}4.1 \\
6.3 \\
4.1\end{array}$ & $\begin{array}{l}1.5 \pm \\
1.5 \\
1.22\end{array}$ & $\begin{array}{l}2.7 \\
4.2 \\
3.6\end{array}$ & 3.5 \\
\hline \multirow{5}{*}{6.0} & 5931 & $\begin{array}{l}\text { Intra- } \\
\text { venous }\end{array}$ & $\begin{array}{l}0 \text { to } 69 \text { mins. } \\
69 \text { to } 129 \\
129 \text { to } 250 \\
250 \text { to } 490\end{array}$ & $\begin{array}{c}72 \\
65 \\
18 \\
4.8\end{array}$ & $\begin{array}{l}20 \\
8 \\
3 \\
0.52\end{array}$ & $\begin{array}{l}3.6 \\
8.1 \\
6.0 \\
3.5\end{array}$ & 7.1 \\
\hline & 5825 & $\begin{array}{l}\text { Intra- } \\
\text { venous }\end{array}$ & $\begin{array}{l}0 \text { to } 1 \mathrm{hrs} \\
1 \text { to } 2 \\
2 \text { to } 3 \\
3 \text { to } 4\end{array}$ & $\begin{array}{l}37.9 \\
27 \\
26.7 \\
19\end{array}$ & $\begin{array}{l}30 \\
15 \\
8.1 \\
5.1\end{array}$ & $\begin{array}{l}1.3 \\
1.8 \\
3.3 \\
3.7\end{array}$ & 2.0 \\
\hline & 5912 & $\begin{array}{l}\text { Intra- } \\
\text { muscular }\end{array}$ & $\begin{array}{l}0 \text { to } 74 \text { mins. } \\
74 \text { to } 131 \\
131 \text { to } 253 \\
253 \text { to } 495\end{array}$ & $\begin{array}{r}15 \\
31.5 \\
28.7 \\
4.0\end{array}$ & $\begin{array}{l}8 \pm \\
9.6 \\
8.4 \\
1.5\end{array}$ & $\begin{array}{l}2 . \pm \\
3.3 \\
3.4 \\
2.7\end{array}$ & 2.9 \\
\hline & 5973 & $\begin{array}{l}\text { Intra- } \\
\text { muscular }\end{array}$ & $\begin{array}{l}0 \text { to } 31 \text { mins. } \\
31 \text { to } 65 \\
65 \text { to } 130\end{array}$ & $\begin{array}{l}12.8 \\
36.2 \\
16.5\end{array}$ & $\begin{array}{l}5 \pm \\
7.4 \\
7.6\end{array}$ & $\begin{array}{l}2.5 \\
4.9 \\
2.2\end{array}$ & 3.2 \\
\hline & 6038 & $\begin{array}{l}\text { Intra- } \\
\text { muscular }\end{array}$ & $\begin{array}{l}6 \text { to } 21 \text { mins. } \\
21 \text { to } 65 \\
65 \text { to } 130 \\
130 \text { to } 243 \\
243 \text { to } 360 \\
360 \text { to } 474 \\
474 \text { to } 24 \text { hrs. }\end{array}$ & $\begin{aligned} 31.9 \\
87.3 \\
78.3 \\
31.2 \\
21.5 \\
8.0 \\
0.4\end{aligned}$ & $\begin{array}{c}7.6 \\
16.5 \\
12.5 \\
9.0 \\
4.0 \\
1.22 \\
?\end{array}$ & $\begin{array}{l}4.2 \\
5.3 \\
6.3 \\
3.5 \\
5.4 \\
6.6 \\
?\end{array}$ & 5.2 \\
\hline
\end{tabular}

* The lot A injected contained 18 units per mgm. To translate these data to units, figures in these columns should be multiplied by 0.018 .

It is possible that bacitracin is excreted only by glomerular filtration, and that the large differences obtained in the ratio of bacitracin clearance: thiosulfate clearance, which varied from 0.5 to 1.8 , averaging 1 , were due to technical factors in the collection of urine and in the assay of activity (page 919). It is, however, also possible that there is a certain amount of tubular secretion, and that nephrotoxic products known to be present in the crude bacitracin here used (11) exerted a variable inhibitory effect on the renal excretion. The degree to which bacitracin is bound by serum protein is now under study.

In any event, it is evident that the active material in the crude preparations of bacitracin here used was cleared by the kidney at a rate approximating that of glomerular filtration, while penicillin is cleared at a rate approximating the total renal plasma flow.
Against the C-203 strain of streptococcus here used, the most potent preparation of bacitracin so far available ( $P B-1)$ was gravimetrically only $1 / 12$ as active as penicillin $G$ in vitro. Unless the active material in this preparation constituted only a small fraction of its solid content, even the more favorable pharmacologic properties of bactracin might not counterbalance its relatively low bactericidal activity against this particular strain. However, for organisms against which bacitracin has an activity in vitro comparable with that of penicillin, its slower excretion and more sustained blood levels might permit cure to be effected with smaller doses, or with injections administered at less frequent intervals, than is the case with penicillin.

\section{SUM MARY}

1. Three different lots of "bacitracin," antibiotic concentrates derived from culture filtrates of B. subtilis (Tracy), have been studied with respect to blood levels, urinary excretion, and renal clearance in rabbits and man.

2. The serum concentration after the intravenous or intramuscular injection of bacitracin varied linearly with dosage over a wide range. These serum concentrations fell off far more slowly, and were consistently higher, than was the case with penicillin $\mathrm{G}$, similarly administered.

Two to 4 hours after injection, the serum levels of bacitracin were 10 to 50 times higher than those of penicillin similarly injected; and concentrations in excess of a given level were maintained 4 to 8 times longer.

3. Corresponding to the sustained blood levels, the rate of urine excretion of bacitracin remained at a fairly constant level for a period of 2 to 4 hours after its intramuscular injection.

(a) In man, the cumulative urinary excretion of bacitracin, 1,2, 4, and 6 hours after its intramuscular injection, averaged $17,36,66$, and 87 per cent of the amount injected. The hourly excretion in the first hour was one-third that of penicillin $G$; but after 2 hours, bacitracin was being excreted at a rate 5 times that of penicillin $\mathrm{G}$.

(b) In rabbits, the cumulative totals of bacitracin excreted in 1, 2, and 4 hours averaged 17, 34 , and 62 per cent of the amount injected. Initially, bacitracin was excreted at less than $1 / 3$ the 


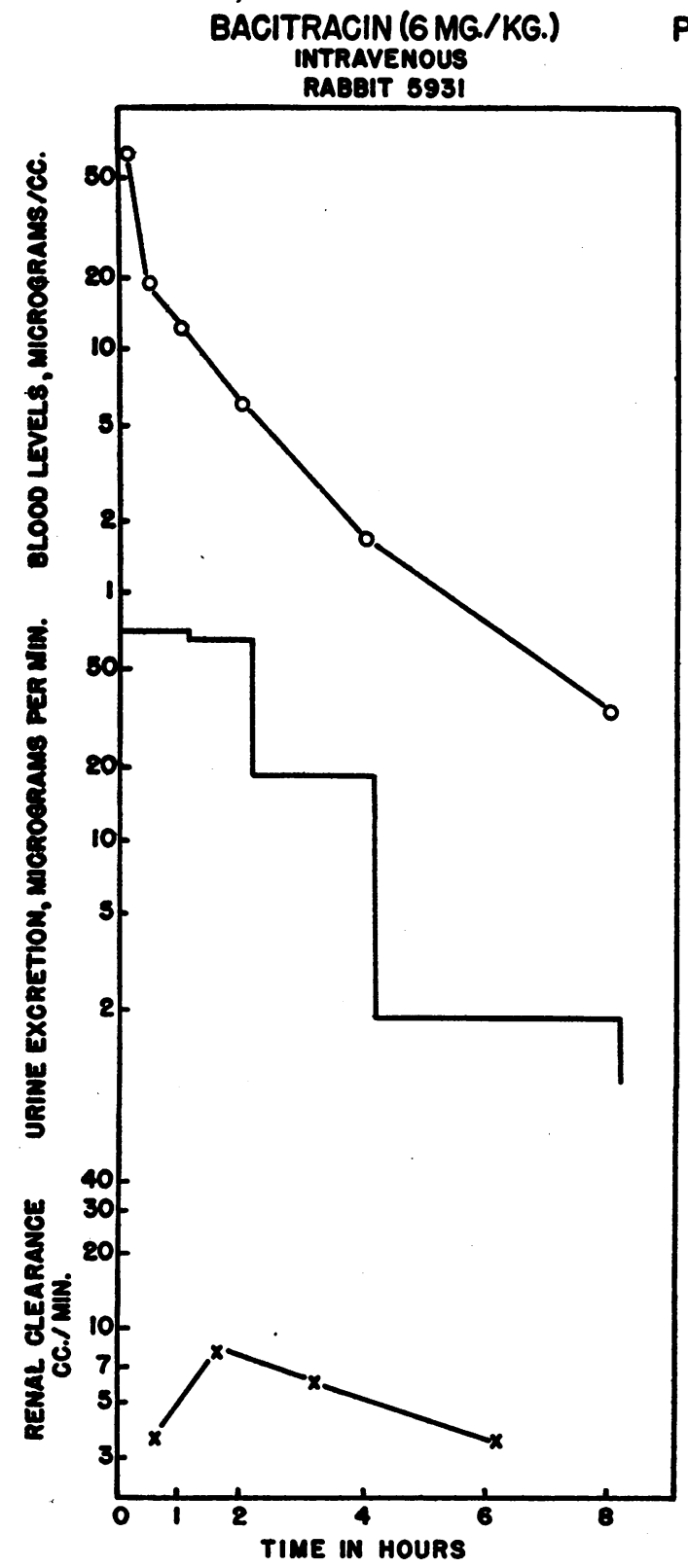

PENICILLIN (0.6 MG./KG) INTRAVENOUS RABBIT 8488

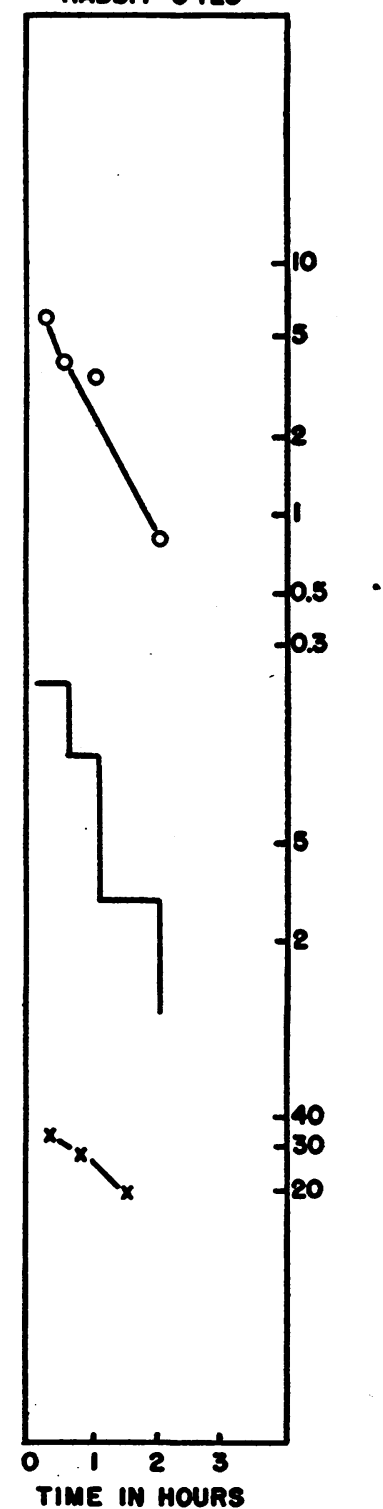

Fig. 6. Illustrating the Low Renal Clearance of Bacitracin in Rabbits, Compared to that of Penicilin

The dosages and corrections are expressed in the figure as mgm. per kgm. in order to permit comparison with penicillin. To obtain the serum concentrations and urine excretions in units, the microgram values should be multiplied by 0.018 .

rate of penicillin; but after 2 hours, the rate of excretion was 1.7 times that of penicillin $G$.

4. The prolonged blood levels of bacitracin as compared with penicillin $G$, and its slower urinary excretion, are explained by its low renal clearance, which approximated the glomerular filtration rate. (a) The renal clearance of bacitracin in 9 human subjects varied between 105 and $283 \mathrm{ml}$. per minute, averaging 159.

(b) In 8 rabbits, the renal clearance of bacitracin varied from 2 to $7 \mathrm{ml}$. per minute, averaging 4.1. 
(c) In both man and rabbits, the renal clearance of penicillins $F, G$, and $X$ for rabbits has previously been shown to approximate the total renal plasma flow.

\section{BIBLIOGRAPHY}

1. Rantz, L. A., and Kirby, W. M. M., Absorption and excretion of penicillin following continuous intravenous and subcutaneous administration. J. Clin. Invest., 1944, 23, 789.

2. Eagle, H., and Newman, E. V., The renal clearance of penicillins $F, G, K$, and $X$ in rabbits and man. J. Clin. Invest., 1947, 26, 903.

3. Eagle, $H$., The varying blood levels afforded by penicillins $F, G, K$, and $X$ in rabbits and man. $J$. Exp. Med., 1947, 85, 163.

4. Johnson, B. A., Anker, H., and Meleney, F. L., Bacitracin: A new antibiotic produced by a member of the B. subtilis group. Science, 1945, 102, 376.

5. Rammelkamp, C. H., A method for determining the concentration of penicillin in body fluids and exudates. Proc. Soc. Exp. Biol. and Med., 1942, 51, 95.
6. Kirby, W. M., and Rantz, L. A., Methods of measuring penicillin concentrations in body fluids. J. Bact., 1944, 48, 603.

7. Eagle, $H$., The inactivation of penicillins $F, G, K$, and $\mathrm{X}$ by human and rabbit serum. J. Exp. Med., 1947, $85,141$.

8. Tucker, H. A., and Eagle, H., The serum concentrations of Penicillin G in man following its intramuscular injection in aqueous solution and in peanut oil beeswax suspension. In press.

9. Newman, E. V., Gilman, A., and Philips, F. A., The renal clearance of thiosulfate in man. Bull. Johns Hopkins Hosp., 1946, 79, 229.

10. Walker, A. M., Schmidt, C. F., Elsom, K. A., and Johnston, C. G., Renal blood flow of unanesthetized rabbits and dogs in diuresis and antidiuresis. Am. J. Physiol., 1937, 118, 95.

11. Scudi, J. V., and Antopol, W., Some pharmacological characteristics of bacitracin. Proc. Soc. Exp. Biol. \& Med., 1947, 64, 503.

Scudi, J. V., Clift, M. E., and Krueger, R. A., Some pharmacologic characteristics of Bacitracin. II. The absorption and excretion of bacitricin in the dog. In press. 